\title{
MENINGKATKAN KREATIVITAS SISWA MELALUI KEGIATAN LOMBA GAMBAR BERCERITA DI SD 226 PALEMBANG
}

\author{
Mukhsin Patriansah"1), Bobby Halim', M. Edo Pratama Putra1) \\ ${ }^{1)}$ Prodi Desain Komunikasi Visual, Fakultas IImu Pemerintahan dan Budaya, Universitas Indo Global Mandiri, \\ Palembang, Sumatera Selatan, Indonesia \\ Corresponding author: Mukhsin Patriansah \\ E-mail : mukhsin_dkv@uigm.ac.id
}

\section{Diterima 08 Maret 2021, Direvisi 17 Maret 2021, Disetujui 17 Maret 2021}

\begin{abstract}
ABSTRAK
Menggambar merupakan suatu media belajar yang bisa meningkatkan kepribadian anak, kepekaan rasa, proses imajinatif, kemampuan kreatif, dan pengembangan intelektual. Menggambar bagi anak sama halnya dengan bermain, dengan bermain anak bisa menemukan suatu kebebasan dan kegembiraan. Dengan demikian, melalui kegiatan menggambar seorang anak mampu menemukan jati diri mereka baik dalam berekspresi, berkreasi dan berkomunikasi. Sebagai sarana meningkatkan minat siswa dalam mengikuti kegiatan menggambar, maka diadakan sebuah kompetisi malalui lomba gambar bercerita yang dilaksanakan di SD 226 Palembang yang melibatkan 30 peserta siswa. Tujuan utama dari kegiatan yang dilaksanakan adalah menyalurkan bakat dan mengembangkan skill (keterampilan) siswa SD 226 Palembang dalam bidang seni menggambar. Di samping itu, tujuan dari kegiatan ini adalah memberikan edukasi dan mampu meningkatkan kualitas guru SD 226 Palembang yang mengajar pada mata pelajaran ekstrakulikuler, khususnya menggambar agar mampu melihat dan memotivasi anak didiknya yang memiliki potensi di bidang seni menggambar, sehingga bakat dan kemampuan mereka benar-benar tersalurkan. Capaian yang diharapkan dari kegiatan ini cukup potensial, hal ini dapat dilihat dari tingginya minat siswa dan sebagian besar siswa sudah memiliki bakat dan keterampilan menggambar yang baik. Bakat dan keterampilan yang dimiliki peserta dapat dilihat dari gambar yang dihasilkan cukup menarik dan memiliki nilai estetis baik dari segi bentuk, ide dan gagasan, serta unsur cerita yang ada di dalamnya.
\end{abstract}

Kata kunci: menggambar; imajinatif; kreativitas; ekstrakulikuler.

\begin{abstract}
Drawing is a learning medium that can enhance a child's personality, sense sensitivity, imaginative processes, creative abilities, and intellectual development. Drawing for children is the same as playing, by playing children can find freedom and joy. Thus, through drawing activities a child is able to find their identity both in expression, creation and communication. As a means of increasing student interest in participating in drawing activities, a competition was held through a storytelling drawing competition held at SD 226 Palembang which involved 30 student participants. The main purpose of the activities carried out is to channel talents and develop skills (skills) of SD 226 Palembang students in the art of drawing. In addition, the purpose of this activity is to provide education and be able to improve the quality of SD 226 Palembang teachers who teach extracurricular subjects, especially drawing in order to be able to see and motivate their students who have potential in the art of drawing, so that their talents and abilities are true funneled right. The achievement expected from this activity is quite potential, this can be seen from the high interest of students and most students already have talent and good drawing skills. The talents and skills possessed by the participants can be seen from the images produced which are quite interesting and have aesthetic values both in terms of shapes, ideas and ideas, as well as the elements of the story in them.
\end{abstract}

Keywords: drawing; imaginative; creativity; extracurricular.

PENDAHULUAN

Pendidikan memiliki peranan yang sangat penting dalam mewujudkan sumber daya manusia yang berkualitas, berkarakter dan mampu berkompetisi di era globalisasi. Optimalisasi sistem pendidikan harus dipersiapkan dengan sebaik-baiknya mulai dari bangku Sekolah Dasar (SD) hingga Perguruan Tinggi. Maka dari itu, perlu adanya suatu pondasi yang kuat untuk menjembatani dan menyalurkan bakat anak dalam berbagai bidang ilmu, salah satunya adalah mengasah pengetahuan dan keterampilan anak melalui kegiatan belajar ekstrakulikuler. 
Pendidikan merupakan suatu aktivitas yang bertujuan untuk mengembangkan dan meningkatkan pengetahuan dan kepribadian dengan melihat potensi-potensi setiap individu seseorang. Hal ini sejalan dengan pendapat Salam di dalam bukunya menjelaskan bahwa pendidikan pada dasarnya adalah salah satu kegiatan yang bertujuan mengembangkan kepribadian seseorang dan sekaligus mempersiapkannya menjadi masyarakat yang mandiri dan bertanggung jawab (Salam, 2001). Jenjang paling dasar dalam memperoleh pendidikan adalah Sekolah Dasar. Pada jenjang inilah seorang anak akan dididik dengan ilmu pengetahuan yang bersifat dasar, mulai dari ilmu matematika, bahasa Indonesia, IImu Pengetahuan Alam, IImu Pengatahuan Sosial, hingga pembelajaran ekstrakulikuler. Dengan adanya proses pembelajaran ekstrakulikuler yang diterapkan di Sekolah Dasar mampu mengembangkan daya kreativitas siswa khususnya dibidang seni.

Pendidikan seni yang diterapkan disekolah dasar sangat penting untuk mengembangkan kepribadian anak, kepekaan rasa, proses imajinatif, kemampuan kreatif, dan pengembangan intelektual. Seperti yang diungkapkan oleh Ismiyanto bahwa melalui pendidikan seni peserta didik akan mampu menghasilkan dan melakukan kegiatan seni yaitu mampu berekspresi, memiliki kemampuan untuk berkreasi, dan menghargai karya orang lain (apresiasi) (Ismiyanto, 2003, p. 35).

Proses pembelajaran ektrakulikuler melalui pendidikan seni begitu beragam, salah satunya adalah kegiatan menggambar. Menurut Riyanto dan Handoko di dalam bukunya menjelaskan bahwa, menggambar merupakan salah satu bentuk pendidikan seni yang diberikan pada anak usia dini. Aktivitas menggambar dimaknai untuk membentuk dan mengembangkan kepribadian anak agar kemampuan logika dan emosinya bertumbuh seimbang (Riyanto, Theo dan Handko, 2004, p. 10). Bagi anak-anak menggambar merupakan suatu proses kreatif dan imajinatif dalam menanggapi suatu objek, yang kemudian diekspresikan dan dituangkan ke dalam medium gambar. Secara konseptual menggambar dapat diartikan juga sebagai representasi dari suatu objek yang diamati. Proses ini lebih bersifat memindahkan suatu objek yang diamati ke dalam medium gambar. Kebanyakan wujud dari sebuah gambar berupa tampilan realistis hasil dari pengamatan terhadap kehidupan sehari-hari. Di samping itu, wujud dari sebuah gambar juga bisa berupa bentuk-bentuk kartun, komik, bahkan ada juga yang dihadirkan dalam bentuk abstrak.
Sangat penting kiranya bagi siswa SD untuk menyalurkan bakatnya melalui kegiatan menggambar. Secara tidak langsung kegiatan menggambar mampu meningkatkan kemampuan motorik halus anak dan mengembangkan daya kreativitas anak. Pengalaman yang diperoleh melalui kegiatan menggambar ini mampu mengembangkan bakat dan kemampuan seorang anak baik dari segi intelektual, keterampilan (skill), kepekaan rasa (emosional), dan kepercayaan diri (keberanian). Menggambar bagi anak sama halnya dengan bermain, dengan bermain anak bisa menemukan suatu kebebasan dan kegembiraan. Dengan demikian, melalui kegiatan menggambar seorang anak mampu menemukan jati diri mereka baik dalam berekspresi, berkreasi dan berkomunikasi.

Fungsi lain dari kegiatan menggambar adalah sebagai sarana bagi siswa Sekolah Dasar untuk belajar sambil bermain. Imajinasi seorang anak akan lebih aktif ketika mereka bermain. Hal ini dikarenakan sebagian besar anak pada usia ini lebih tertarik bermain dari pada belajar. Kebanyakan dari mereka belajar itu merupakan sesuatu yang sangat membosankan. Maka dari itu diperlukan suatu strategi khsusus untuk mengatasi kejenuhan anak dalam mengikuti proses pembelajaran di bangku sekolah, salah satunya melalui kegiatan menggambar. Kegiatan menggambar cukup efektif untuk menciptakan suasana belajar yang kondusif, efektif dan menyenangkan (enjoyable learning). Penjelasan ini senada dengan yang diungkapkan Sabaryati bahwa dalam Pembelajaran di Sekolah Dasar, permainan merupakan salah satu media yang tidak dapat diabaikan keberadaannya. Hal ini karena anak usia sekolah dasar masih mempunyai ketertarikan yang besar dengan permainan sesuai dengan kematangan jiwanya sehingga dapat belajar dan bermain (playing by learning) (Sabaryati, 2020, p. 241).

Uraian yang sudah dijabarkan di atas menjadi ketertarikan bagi penulis untuk melaksanakan kegiatan lomba gambar bercerita. Di samping itu, kegiatan ini merupakan sarana untuk menciptakan antusiasme siswa dalam mengikuti kegiatan menggambar. Proses kegiatan ini dilaksanakan di SD Negeri 226 Palembang yang beralamat di Plaju Darat, Kecamatan Plaju, Kota Palembang Sumatera Selatan. 


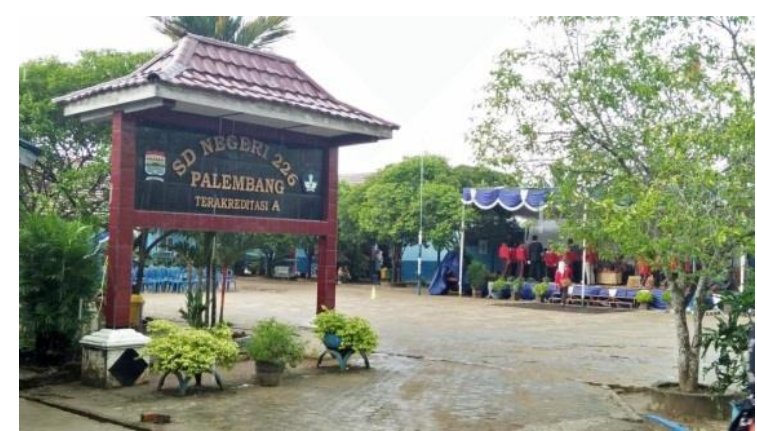

Gambar 1. Lokasi kegiatan lomba gambar bercerita di sd 226 palembang.

(Sumber Foto: Mukhsin Patriansah, 2020).

Kegiatan lomba gambar bercerita yang dilaksanakan di SD 226 Palembang ini dilaksanakan karena adanya kerjasama dengan pihak sekolah untuk mempersiapkan siswanya dalam ajang Festival dan Lomba Seni Siswa Nasional (FLS2N) tingkat Kabupaten dan Kota dan nantinya akan berlanjut pada tingkat Nasional. Pada prinsipnya gambar bercerita memiliki arti yang sangat berbeda dengan cerita bergambar. Gambar bercerita merupakan suatu bahasa rupa anak yang mampu meberikan suatu cerita tanpa mengunakan teks di dalamnya. Sedangkan cerita bergambar merupakan suatu kisah yang diceritakan dengan visual gambar yang menggunakan teks tertulis. Adapun kegiatan lomba gambar bercerita yang dilaksanakan mengusung tema "mewujudkan karakter dan prestasi siswa melalui budaya lokal". Tema ini memiliki tujuan untuk mengenal dan menjaga eksistensi budaya lokal khususnya kebudayaan yang ada di kota Palembang di tengah arus globalisasi.

Anak-anak siswa SD 226 Palembang diharapkan mampu mengimplementasikan gagasan kreatifnya ke dalam medium gambar. Capaian yang diharapkan dari kegiatan ini cukup petensial, hal ini ditandai dari tingginya antusiasme siswa dalam mengikuti kegitan yang dilaksanakan. Di samping itu, banyaknya siswa yang memiliki bakat dan kemampuan dalam mengekspresikan ide dan gagasannya ke dalam medium gambar, hal ini dapat dilihat dari hasil gambar yang telah mereka buat yang sangat menarik dan memiliki nilai estetis baik dari segi bentuk, tampilan visual dan ide atau gagasan yang diekspresikan.

Target utama dari kegiatan yang dilaksanakan adalah menyalurkan bakat dan mengembangkan skill (keterampilan) siswa SD 226 Palembang dalam bidang seni menggambar. Target lain yang diusung dari kegiatan ini adalah memberikan edukasi dan mampu meningkatkan kualitas guru yang mengajar pada mata pelajaran ekstrakulikuler, khususnya menggambar agar mampu melihat dan memotivasi anak didiknya yang memiliki potensi di bidang seni menggambar untuk lebih diasah kemampuannnya, sehingga bakat dan kemampuan mereka benar-benar tersalurkan. Hal ini dikarenakan guru sebagai tenaga pendidik memiliki andil yang cukup besar dalam melihat dan mengembangkan bakat serta potensi yang dimiliki anak didiknya.

\section{METODE}

Dalam Ensiklopedi Indonesia disebutkan bahwa, metodologi adalah ilmu tentang cara atau langkah untuk menganalisa sesuatu yang baru (Shadly, 1990, p. 45). Dengan demikian metode dapat diartikan juga sebagai suatu cara atau langkah-langkah yang dilakukan untuk menyelesaikan suatu permasalahan yang telah dirumuskan (Patriansah et al., 2021, p. 61). Berdasarkan pengamatan yang dilakukan melalui kegiatan lomba gambar bercerita adalah tingginya minat siswa yang ikut berpartisipasi dalam kegiatan lomba ini. Di samping itu, sebagian besar dari mereka memiliki bakat dan keterampilan dalam bidang seni menggambar. Dengan demikian, diperlukan suatu metode khusus untuk memberikan suatu pengetahuan dasar kepada siswa SD 226 Palembang sebagai bekal mereka dalam mengembangkan bakat dan potensi di bidang seni menggambar.

Menurut Pramutoko,dkk (2017: 14) "beberapa metode pendekatan dalam pengabdian kepada masyarakat dapat dilakukan dengan observasi dan wawancara, penyuluhan, partisipatif, pembinaan, pelatihan dan pendampingan". Pada dasarnya kegiatan ini juga mengacu pada metode pengabdian secara umum. Sebagai upaya menyelesaikan suatu permasalahan yang telah dirumuskan di latar belakang, diperlukan suatu metode dan pendekatan khusus yang efektif. Secara keseluruhan kegiatan ini dilaksanakan selama tiga hari. Adapun metode yang dilakukan terdiri dari beberapa langkah dan tahapan di antaranya adalah langkah pertama, sosialisasi yang dilakukan dihari pertama kegiatan berlangsung. Sosialisasi yang dilakukan lebih menitik beratkan kepada pengetahuan dan keterampilan dasar menggambar, seperti teknik menggambar yang benar, penyesuaian gambar dengan tema serta pengenalan alat dan bahan yang digunakan. Di samping itu dilakukan juga demonstrasi dengan cara mempraktikan secara langsung kepada seluruh peserta lomba.

Langkah kedua adalah proses kegiatan lomba gambar bercerita yang dilaksanakan pada hari kedua yang diikuti oleh siswa-siswa yang duduk di bangku kelas 4 hingga kelas 6 . Dalam kegiatan ini lebih bersifat mengontrol jalannya kegiatan lomba. Di samping itu juga memberikan sedikit arahan kepada seluruh 
peserta lomba untuk mengutamakan kerapian, proposi dan keseimbangan gambar. Selanjutnya, langkah ketiga adalah penilaian dan evaluasi. Di hari terakhir pelaksanaan kegiatan ini dilakukan suatu penilaian terhadap hasil gambar yang dibuat dari peserta lomba, disamping itu juga dilakukan evaluasi berkaitan langsung dengan hal-hal yang harus dibenahi dan di perbaiki agar peserta lomba bisa melihat sejauh mana capaian gambar yang mereka buat.

\section{HASIL DAN PEMBAHASAN Proses Sosialisasi}

Proses sosialisasi merupakan bagian terpenting dari seluruh rangkaian proses kegiatan lomba gambar bercerita yang dilaksanakan. Proses sosialisasi ini dilakukan dihari pertama kegiatan berlangsung dengan cara memberikan pemahaman kepada peserta lomba mengenai defenisi dari gambar bercerita. Pada dasarnya gambar bercerita dapat diartikan sebagai suatu bahasa rupa yang ditampilkan tanpa menggunakan tek tertulis, akan tetapi bahasa rupa berupa gambar yang dibuat mampu menceritakan sesuatu di dalamnya. Di samping itu, proses sosialisasi yang dilakukan dengan memberikan pengetahuan dan keterampilan dasar mengenai teknik menggambar yang benar, proporsi dan keseimbangan yang tepat, membuat sketsa gambar yang benar, penggunaan warna yang tepat, teknik mewarnai yang benar, dan penyesuaisan gambar dengan tema yang telah ditentukan.

$$
\text { Selama kegiatan berlangsung }
$$

mendapat respon positif dari siswa SD 226 Palembang, hal ini dapat dilihat dari tingginya antusiasme siswa yang mengikuti lomba. Tingginya minat siswa menjadikan kegiatan ini lebih menarik dan lebih kompetitif. Kegiatan lomba gambar bercerita ini diikuti 30 peserta siswa yang terdiri dari 7 siswa dari kelas 4,10 siswa dari kelas 5 dan 13 siswa dari kelas 6 . Sebagai upaya agar peserta lomba dapat mendapatkan ilmu dari kegiatan ini, maka dilakukan demonstrasi dengan cara mempraktikan secara langsung kepada seluruh peserta. Dengan demikian, siswa benar-benar mendapatkan langsung pengalaman berupa pengetahuan dasar menggambar. Dalam tahapan sosialisasi ini peserta langsung memilih dan menentukan judul yang akan digunakan pada saat lomba.

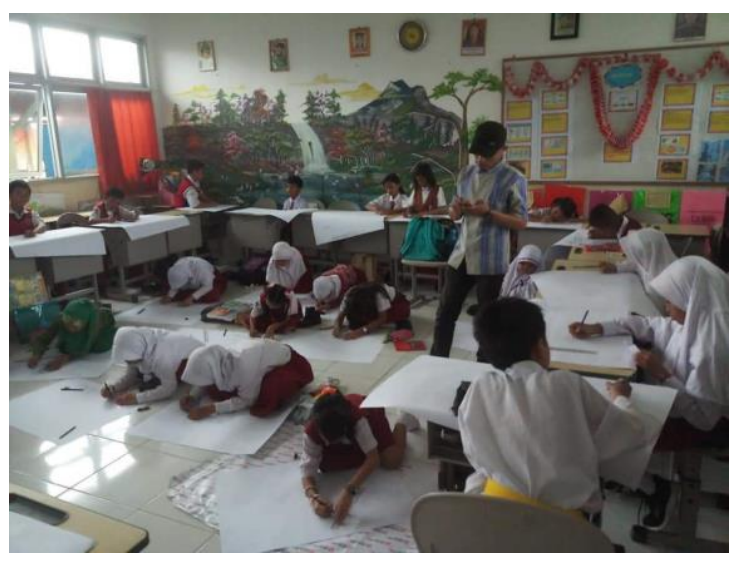

Gambar 2. Dokumentasi proses sosialisasi dan demontrasi kegiatan lomba gambar bercerita. (Sumber Foto : Idris, 2020)

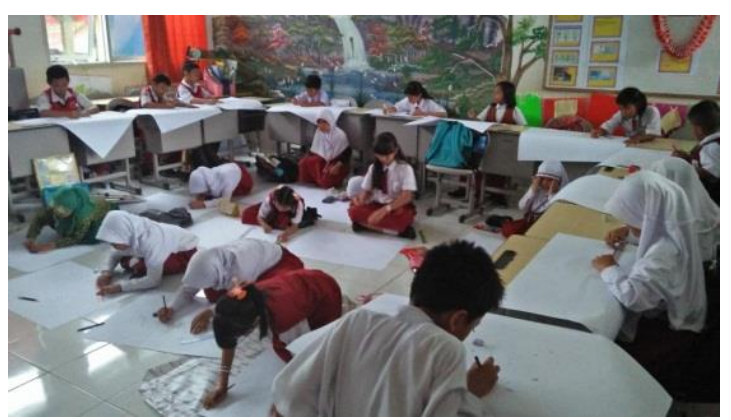

Gambar 3. Dokumentasi proses sosialisasi dan demontrasi kegiatan lomba gambar bercerita. (Sumber Foto : Mukhsin Patriansah, 2020)

Pengenalan alat dan bahan merupakan tahapan yang sangat penting dari suatu kegiatan pelatihan. Melalui tahapan ini diharapkan peserta pelatihan dapat menguasail dan mengetahui fungsi dari alat dan bahan yang digunakan. Kegiatan lomba gambar bercerita ini menggunakan alat dan bahan yang sering mereka gunakan dalam kegiatan menggambar pada umumnya. Adapun alat dan bahan yang digunakan dapat dilihat pada tabel 1 berikut :

Tabel 1. Jenis-jenis alat dan bahan yang digunakan

\begin{tabular}{|l|l|l|}
\hline No & Alat dan Bahan & Fungsi \\
\hline 1. & & $\begin{array}{l}\text { Kertas Gambar } \\
\text { Drawing Paper } \\
\text { ukuran A1. } \\
\end{array}$ \\
& $\begin{array}{l}\text { Digunakan } \\
\text { sebagai bahan } \\
\text { atau media } \\
\text { gambar. Kertas } \\
\text { drawing paper } \\
\text { sangat cocok } \\
\text { bagi pemula dan } \\
\text { harganya juga } \\
\text { sangat tejangkau }\end{array}$ \\
\hline
\end{tabular}




\begin{tabular}{|c|c|}
\hline & $\begin{array}{l}\text { dan mudah di } \\
\text { temukan }\end{array}$ \\
\hline 2. & $\begin{array}{l}\text { Pensil yang } \\
\text { digunakan } \\
\text { adalah pensil HB } \\
\text { dan } 2 \text { B. pensil } \\
\text { jenis ini sangat } \\
\text { cocok digunakan } \\
\text { sebagai alat } \\
\text { untuk membuat } \\
\text { sketsa gambar. }\end{array}$ \\
\hline 3. & $\begin{array}{l}\text { Peraut pensil } \\
\text { digunakan } \\
\text { sebagai alat } \\
\text { untuk meraut } \\
\text { pensil }\end{array}$ \\
\hline 4. & $\begin{array}{l}\text { Penghapus } \\
\text { digunakan untuk } \\
\text { menghapus atau } \\
\text { menghilangkan } \\
\text { bagian sketsa } \\
\text { gambar yang } \\
\text { salah }\end{array}$ \\
\hline 5. & $\begin{array}{lr}\text { Spidol warna } & \text { wan digunakan } \\
\text { hitam } \\
\text { sebagai penebal } \\
\text { garis sketsa } \\
\text { gambar yang } \\
\text { telah dibuat. }\end{array}$ \\
\hline 6. & $\begin{array}{l}\text { Crayon } \\
\text { digunakan } \\
\text { sebagai alat } \\
\text { mewarnai dari } \\
\text { sketsa gambar } \\
\text { yang telah } \\
\text { dibuat. Crayon } \\
\text { mampu } \\
\text { menghasilkan } \\
\text { warna yang } \\
\text { lebih terang, } \\
\text { jelas dan lebih } \\
\text { hidup. }\end{array}$ \\
\hline 7 & $\begin{array}{l}\text { Penggunaan } \\
\text { penggaris dalam } \\
\text { kegiatan } \\
\text { menggambar } \\
\text { sebenarnya tidak } \\
\text { terlalu penting, } \\
\text { karena } \\
\text { menghasilkan } \\
\text { gambar yang } \\
\text { kaku, namun } \\
\text { demikian ada } \\
\text { bagian tertentu } \\
\text { yang memang } \\
\text { membutuhkan } \\
\text { penggaris, } \\
\text { misalnya } \\
\text { membuat bentuk }\end{array}$ \\
\hline
\end{tabular}

\begin{tabular}{|l|l|}
\hline & $\begin{array}{l}\text { bangunan seperti } \\
\text { gedung yang } \\
\text { bertingkat. }\end{array}$ \\
\hline
\end{tabular}

Proses Kegiatan Lomba Gambar Bercerita

Proses kegiatan lomba gambar bercerita merupakan bagian inti dari pelaksanaan kegiatan ini. Seperti yang sudah dijelaskan di atas tujuan diadakannya lomba gambar bercerita ini adalah menumbuhkan minat dan menyalurkan bakat serta keterampilan siswa SD 226 Palembang terhadap seni menggambar. Ketentuan dan pelaksanaan yang ditetapkan dalam kegiatan lomba gambar bercerita ini adalah peserta siswa wajib mengikuti aturan dan tata tertib yang sudah ditetapkan, seperti tidak boleh berisik, tidak boleh berjalan selama kegiatan berlangsung, tidakboleh memakan makanan, dan tidak boleh keluar masuk ruangan, jika tidak ada hal yang mendesak.

Durasi yang ditetapkan dalam kegiatan lomba ini selama 5 jam yang dimulai dari jam 08.00 pagi sampai dengan jam 12.00 siang, durasi waktu selama 5 jam harus dimanfaatkan sebaik mungkin oleh peserta lomba mulai menentukan judul dan tema gambar yang dibuat, membuat sketsa sampai dengan proses mewarnai sketsa gambar dengan crayon. Dalam proses kegiatan lomba gambar bercerita ini peserta mendapatkan pengarahan dan pengawasan dari tim pelaksana kegiatan lomba.

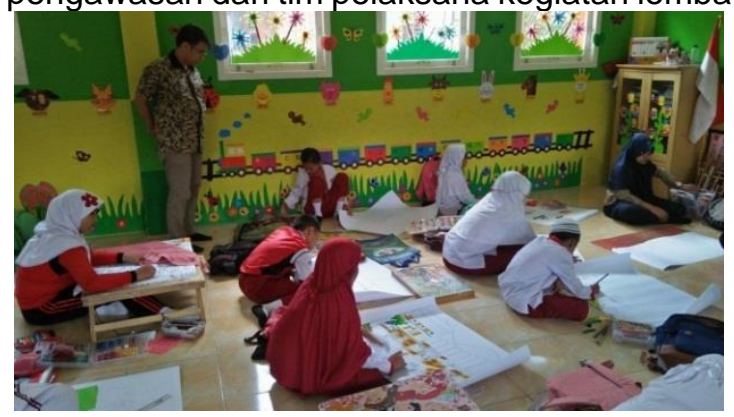

Gambar 4. Dokumentasi kegiatan lomba gambar bercerita (Sumber Foto : Mukhsin Patriansah, 2020)

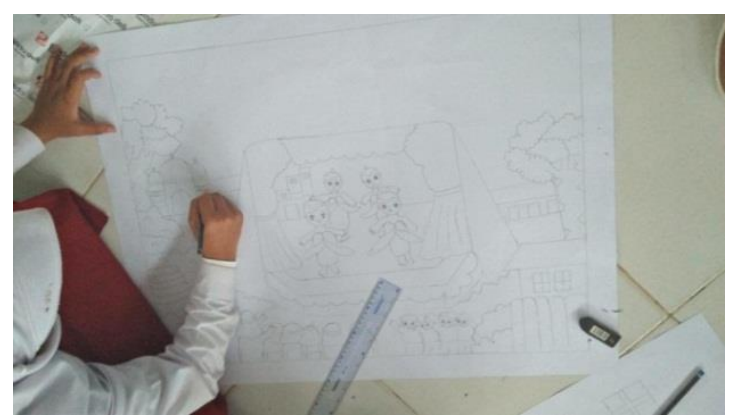

Gambar 5. Dokumentasi kegiatan lomba gambar bercerita (Sumber Foto : Bobby Halim, 2020). 


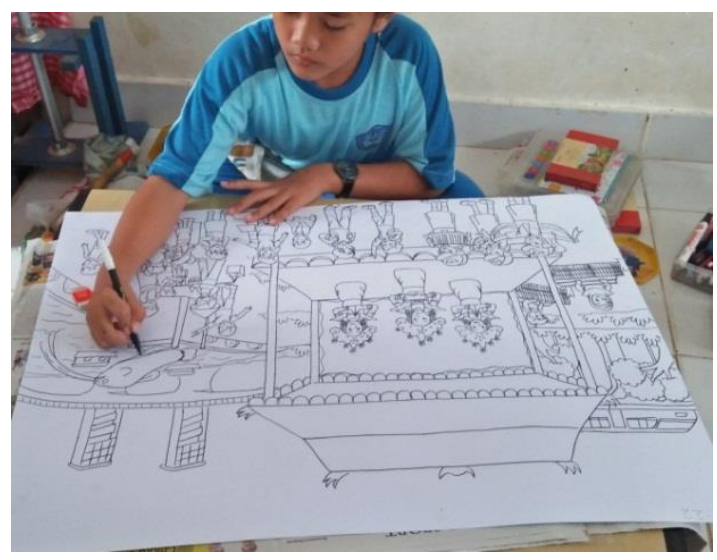

Gambar 6. Dokumentasi kegiatan lomba gambar bercerita (Sumber Foto : Bobby Halim, 2020).

\section{Proses Penilaian dan evaluasi}

Tahapan terakhir dari pelaksanaan kegiatan lomba gambar bercerita ini adalah dilakukan suatu penilaian dan evaluasi terhadap hasil gambar yang dibuat dari peserta lomba. Penilaian dan evaluasi yang dilakukan berkaitan langsung dengan hal-hal yang harus dibenahi dan diperbaiki agar peserta lomba bisa melihat sejauh mana capaian gambar yang mereka buat. Sebagai upaya memicu persaingan yang bersifat kompetitif dari kegitan lomba yang dilaksanakan, maka ditentukan karya terbaik.

Beberapa aspek yang dilihat dalam proses penilaian di antaranya adalah aspek cerita dan aspek gambar. Aspek cerita mencakup kehidupan anak-anak dalam konteks budaya kota Palembang, tampilan gambar yang sederhana, menarik dan komunikatif dan penyesuaian isi cerita yang disampaikan dalam bentuk gambar dengan judul yang dipilih. Aspek gambar dilihat dari keaslian gambar yang dibuat, ide dan gagasan yang diekspresikan, kerapian, keunikan, penguasaan alat dan bahan yang digunakan dan mampu menyusun unsur-unsur seni rupa secara baik, seperti garis, warna, bidang, bentuk yang disusun berdasarkan prinsip penyusunan yakni, keseimbangan, keselarasan, harmoni, dan proporsi gambar.

Secara keseluruhan peserta yang mengikuti kegiatan ini memiliki bakat dan keterampilan menggambar yang baik, hal ini dapat dilihat dari wujud gambar yang dihasilkan cukup menarik dan memiliki nilai estetis baik dari segi bentuk, ide dan gagasan, prinsip penyusunan rupa, dan lainnya. Akan tetapi, ada kekurangan yang perlu diperbaiki, seperti tidak mampu memanfaatkan durasi waktu yang sudah ditentukan oleh panitia pelaksana kegiatan lomba ini, sehingga karya yang dibuat belum selesai secara utuh. Perlu adanya suatu metode khusus yang diterapkan oleh guru yang mengajar mata pelajaran menggambar untuk melatih siswanya sesering mungkin. Sehingga bisa menentukan bentuk gambar yang sederhana agar tidak terlalu memakan waktu yang lama dalam penggarapannya.

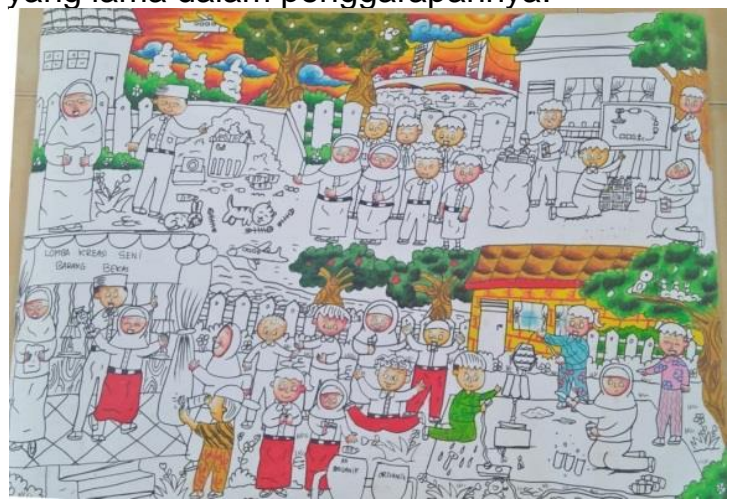

Gambar 7. Dokumentasi karya terbaik pertama. (Sumber Foto : Mukhsin Patriansah, 2020).

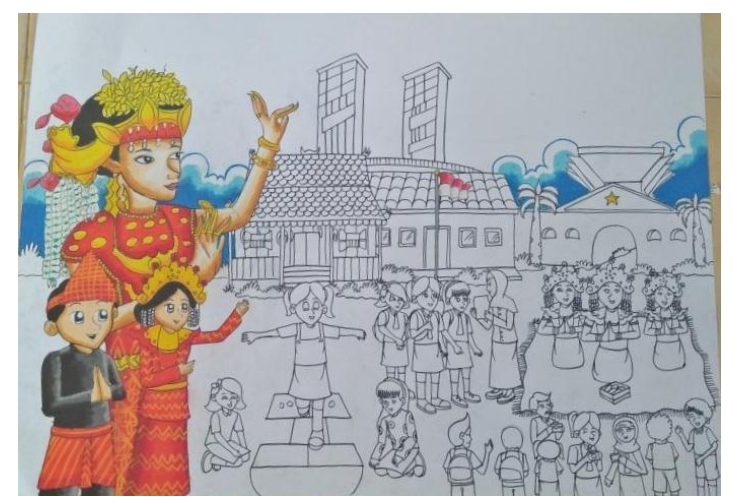

Gambar 7. Dokumentasi karya terbaik kedua

(Sumber Foto: Mukhsin Patriansah, 2020).

\section{SIMPULAN DAN SARAN Simpulan}

Berdasarkan hasil penilaian dan evaluasi terhadap karya yang telah dibuat oleh peserta siswa SD 226 Palembang yang mengikuti kegiatan lomba gambar bercerita dapat ditarik kesimpulan bahwa tingginya semangat dan minat siswa SD 226 Palembang terhadap bidang seni menggambar. Sebagian besar dari mereka banyak yang memiliki bakat dan kemampuan di bidang ini. Melalui kegiatan ini diharapkan siswa dapat menyalurkan dan mengembangkan bakat dan kemampuannya di bidang seni menggambar. Di samping itu, melalui kegiatan ini juga mampu memberikan edukasi dan meningkatkan kualitas guru yang mengajar pada mata pelajaran di bidang seni menggambar agar bisa memotivasi, melihat dan mengembangkan bakat dan kemampuan serta petensi yang dimiliki peserta didiknya.

\section{Saran}

Saran yang ingin disampaikan melalui kegiatan ini adalah perlu adanya suatu kegiatan 
yang dilakukan secara berkelanjutan, untuk mengambangkan potensi siswa SD 226 palembang di bidang seni menggambar. Di samping itu perlu juga dilaksanakan suatu pelatihan khusus terhadap guru untuk meningkatkan kualitas guru agar memiliki ilmu dan pengatahuan dasar tentang seni menggambar.

\section{DAFTAR RUJUKAN}

Ismiyanto, P. S. (2003). Metode Penelitian (S. : B. A. UNNES. (ed.)).

Patriansah, M., Indo, U., Mandiri, G., Yulius, Y., Indo, U., \& Mandiri, G. (2021). Upaya Meningkatkan Perekonomian Warga Desa melalui Pelatihan Kerajinan Bunga dari Akar Kayu. 5(01), 58-66.

Pramutoko, B., \& Astuti, I. Y. (2017). IbM KELOMPOK KERAJINAN BAMBU DI DESA PEHKULON KECAMATAN PAPAR KEDIRI. Jurnal Dedikasi, 14, 12-20.

Riyanto, Theo dan Handko, M. (2004). Pendidikan Anak Usia Dini: Tuntunan Psikologis dan Paedagogis Bagi Pendidikan dan Orang Tua. Jakarta: PT. Gramedia Widya Sarana Indonesia.

Sabaryati, J. (2020). PELATIHAN PEMBUATAN MEDIA PERMAINAN EDUKATIF ( MPE ) DALAM PEMBELAJARAN PADA GURUGURU MADRASAH IBTIDAIYAH NURUL YAKIN. 3, 241-243.

Salam, S. (2001). Pendidikan Seni Rupa Sekolah Dasar. Makassar: Penerbit Universitas Negeri Makassar.

Shadly, H. (1990). Ensiklopedi Nasional Indonesia. Jakarta: PT. Cipta Adi Pustaka. 